\title{
窒化チタンの鋳込成形におけるイットリア添加方法の影響
}

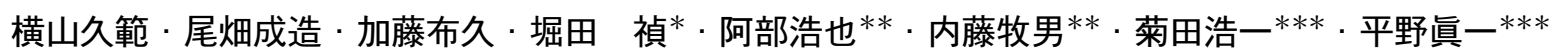 \\ 岐阜県セラミックス技術研究所，507-0811 岐阜県多治見市星ヶ台 3-11 \\ *(財)ファインセラミックスセンター, 456-8587 名古屋市熱田区六野 2-4-1 \\ **大阪大学接合科学研究所, 567-0047 大阪府茨木市美穂ヶ丘 11-1 \\ ***名古屋大学大学院工学研究科化学・生物工学専攻, 464-8603 名古屋市千種区不老町
}

\section{Effect of Addition Procedures of Yttria on Slip Casting of Titanium Nitride}

\author{
Hisanori YOKOYAMA, Seizo OBATA, Nobuhisa KATO, Tadashi HOTTA, ${ }^{*}$ Hiroya ABE, ${ }^{* *}$
} Makio NAITO, ${ }^{* *}$ Kouichi KIKUTA*** and Shin-ichi HIRANO***

\author{
Gifu Prefectural Ceramics Research Institute, 3-11, Hoshigadai, Tajimi-shi, Gifu 507-0811 \\ *Japan Fine Ceramics Center, 2-4-1, Mutsuno, Atsuta-ku, Nagoya-shi 456-8587 \\ **Joining and Welding Research Institute, Osaka University, 11-1, Mihogaoka, Ibaraki-shi, Osaka 567-0047 \\ ***Department of Applied Chemistry, Graduate School of Engineering, Nagoya University, Furo-cho, Chikusa-ku, Nagoya-shi 464-8603
}

\begin{abstract}
The effect of the addition of yttria was investigated on the preparation of titanium nitride aqueous slurry by ballmilling. Slip casting was carried out using the prepared slurries, and the effect of the slurry characteristics on forming and sintering behavior was studied. The amount of the dispersant to minimize the viscosity of the slurry increased with increasing both amount of yttria and milling time. A high density compact with homogeneously dispersed yttria could be prepared by slip casting the slurry prepared by long time milling. Titanium nitride sintered body could also be successfully prepared by firing in nitrogen atmosphere.
\end{abstract}

[Received July 20, 2004; Accepted September 22, 2004]

Key-words : Slip casting, Titanium nitride, Yttria, Aqueous slurry, Slurry characteristics

\section{1. 緒言}

窒化チタン $(\mathrm{TiN})$ セラミックスは, 耐食性・耐熱性を兼備 した高硬度・高融点化合物である。特に，美しい黄金色の色調 を持ち比較的安価であるため, 耐摩耗装飾用焼結体及び切削工 具や装飾用被覆材として利用されている(1),2). また，シリコン なみの電気伝導性を有することから, 静電対策用の導電性付与 剂や放電加工を目的としてアルミナや窒化ケイ素に添加した導 電性セラミックスの開発も多くなされている3 ${ }^{3)}$. 窒化チタン 焼結体は雾囲気焼成 ${ }^{9)}$,10) やホットプレス焼結 ${ }^{10)}$ 13) により作製 される.しかしながら，ホットプレス焼結は炭素モールドから の炭素の拡散による色調退化と複雑形状品の作製が困難なこと から焼結体作製にはあまり適していない。したがって, 窒化チ タン焼結体の成形方法は，ほとんどが有機溶剤などを使用した 混合した粉末のプレス成形によるものである. 現在, 有機溶剤 による人体への影響や工場からの有機溶剤の溶出などの環境問 題から, 窒化チタンにおいても有機溶剤を使わない成形方法の 開発が急務となっている，そこで，著者らは焼結助剤を含まな い窒化チタンの水系鋳込成形についてスラリー特性が成形及び 焼結挙動に与える影響の検討を行った ${ }^{14)}$.

窒化チタンは難焼結性であるため, Co や $\mathrm{Ni}$ 等の金属2,9),10), $\mathrm{TiH}_{2}$ や $\mathrm{B}_{4} \mathrm{C}$ 等の非酸化物 ${ }^{2), 13)}$ 及びイットリアやアルミナ等の 酸化物 ${ }^{13)}$ を焼結助剂に加えて高密度体を得ている。しかしなが ら，水を分散媒に使用する成形方法では，耐水性の低い金属粉 末や非酸化物粉末を使用することができない。また，金属粉末 や非酸化物粉末は微粒子が少なく, 均一分散を特徵とする鋳込 成形には適していない。

一方, 酸化物系の焼結助剂としては, 窒化ケイ素や窒化アル ミニウムと同様にイットリアの添加が効果的である ${ }^{13)}$. 同じ難 焼結性である窒化ケイ素においては, 水を分散媒に用いイット
リア等を添加した鋳込成形やプレス成形の研究が多数報告され ている(5) 20). しかしながら，これらの水系成形に沶いて焼結 助剂に注目し, その混合条件の影響について検討した報告はほ とんどない。

そこで本報では, 窒化チタンの水系スラリ一調製における イットリア添加方法の影響を調べるとともに鋳込成形を行い, スラリー特性が成形及び焼結特性に与える影響について検討を 行った.

\section{2. 実験方法}

\section{1 粉体及び粉体特性}

窒化チタンには TiN-01（日本新金属：平均粒子径 $1.8 \mu \mathrm{m}$, BET 比表面積 $2.2 \mathrm{~m}^{2} / \mathrm{g}$ ) を使用し, 焼結助剤にはイットリア NRN (第一稀元素工業: 平均粒子径 $0.3 \mu \mathrm{m}, \mathrm{BET}$ 比表面積 25.6 $\mathrm{m}^{2} / \mathrm{g}$ ) を使用した。 また, 超音波方式のゼータ電位測定装置 (Dispersion Technology 製, DT-1200) を用い 2 vol\%スラリー のゼータ電位と $\mathrm{pH}$ の関係を調べた.

\section{2 窒化チタンスラリーの調製方法}

鋳込成形用のスラリーは, 窒化チタンのみのスラリー（以下 基礎スラリーと言う）を調製し，そのスラリーにイットリアを 添加, 再調製する方法で作製した. 基礎スラリーはアンモニア 水により $\mathrm{pH}$ を9.6〜 9.8に調整したイオン交換水に粉体を混合 することによって調製した。基礎スラリーの粉体濃度は 80 $\operatorname{mass} \%, \phi 5 \mathrm{~mm}$ のジルコニア製ボールを用い $24 \mathrm{~h}$ 混合した. 調 製した基礎スラリーにイットリア添加量が 5 mass \%, 10 mass \% となるように粉体と水を加え, 全体の粉体濃度を 80 mass\%に 再調製し, $2 \mathrm{~h}, 6 \mathrm{~h}, 24 \mathrm{~h}$ の各時間ボールミル混合を行った.こ のとき, 分散剤としてポリアクリル酸アンモニウム塩（PAA） を添加した。 


\section{3 スラリー特性}

調製したスラリーを真空脱泡した後, 回転粘度計（芝浦シス テム製，VEA-K）により見掛け粘度を測定した.ローターに はB 型 No. 3 を用い, $25^{\circ} \mathrm{C}$ におけるずり速度を $12.7 \mathrm{~s}^{-1}$ とし， 測定 $1 \mathrm{~min}$ 後の值を見掛け粘度とした。また， $\mathrm{pH}$ 計にてスラ リーの $\mathrm{pH}$ を測定した。

\section{4 鋳込成形及び成形体特性}

スラリーをセッコウ型 $(65 \times 65 \times 7 \mathrm{~mm})$ に流し込久, 固形鋳 込成形を行った. 固化した成形体を型から取り出し, 自然乾燥 後寸法と重量から成形体密度を計算した。 また, 成形体の比表 面積を BET 吸着法 (Quantachrome 製, AS-1M) により測定し た. 更に, 走查型電子顕微鏡 (SEM ; 日立製作所製, S-2400) により成形体破面の観察を行った.

\section{5 焼成及び焼結体特性}

燒成は $0.75 \mathrm{MPa}$ 窒素雾囲気, $1850^{\circ} \mathrm{C}, 3 \mathrm{~h}$ にて行った。得ら れた焼結体の密度をアルキメデス法により求めた. SEMによ り研削面の組織観察を行った。 また, X 線回折装置 (マックサ イエンス製，MXP3VA）により結晶相の同定を行った.

\section{3. 実験結果}

\section{1 粉体特性}

図 1 に各粉体の $\mathrm{pH}$ とゼータ電位の関係を示す。窒化チタン はアルカリ域で負の電位を持ち, 等電点は約 5 であり, 中性か らアルカリ域では負の電位を示した。一方，イットリア粉体は 弱アルカリ域でも正の電位であり, 等電点は約11であった. イットリアの等電点は9 9 10.6という報告 ${ }^{21)} 23$ ) があり，これら の結果に近い值となった.

\section{2 スラリー特性}

図 2 にPAA 添加量とスラリーの pH の関係を示す.スラリー の $\mathrm{pH}$ はいずれの場合も 9.6〜 10.3の範囲にあることが分かる. また, $\mathrm{pH}$ が最大となる PAA 添加量が示された. 同じ混合時 間で比較すると，イットリア添加量が 5 mass\%の方が $\mathrm{pH}$ は高 くなった．また，いずれのイットリア添加の場合も混合時間が 長くなるほど $\mathrm{pH}$ が高くなった.イットリアを水系で混合した 場合, 混合時間が長くなるほどイットリアが水和され，pH が 高くなることが報告されている22),23). 今回, 混合時間が長いほ ど $\mathrm{pH}$ が高くなった原因には，イットリアの水和反応も影響し ていると考える.

図 3 にPAA 添加量とスラリーの見掛け粘度の関係を示す. いずれのイットリア添加量や混合時間においても PAAの添加 によってスラリー粘度が変化し, 粘度が最も低くなる PAA 添 加量が認められた。しかし，粘度を最小とする PAA 添加量は 混合時間が長くなるほど増加し，いずれのイットリア添加量で も $24 \mathrm{~h}$ 混合の場合 $2 \mathrm{~h}$ 混合に比べて約 2 倍の PAA 添加量が必 要となった。 また，イットリア添加量 5 mass $\%$ と 10 mass $\%$ の スラリーを比較すると，混合時間に関係なく 5 mass\%よりも 10 mass\%の方が PAAの添加量が約 2 倍必要となった. 更に, 粘 度が最小となったPAA 添加量に抢ける粘度は，イットリア添 加量が同じ場合は同程度となり，その粘度は 5 mass \%の方がわ ずかに低くなった.

\section{3 成形体特性}

図 4 にスラリーの見掛け粘度と成形体密度の関係を示す。成 形体の密度はスラリーの粘度により変化し，いずれのイットリ ア添加量及び混合時間においても, 粘度が低いスラリーから高 い密度の成形体が得られた．イットリア添加量が 5 mass \%の場 合，混合時間にほぼ関係なく低粘度のスラリーから同程度の密 度を有する成形体が得られた。一方, 添加量が 10 mass \%の場

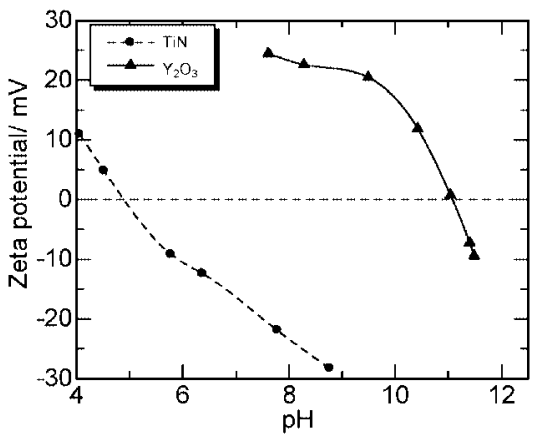

Fig. 1. Zeta potential curve of the suspension of powders.
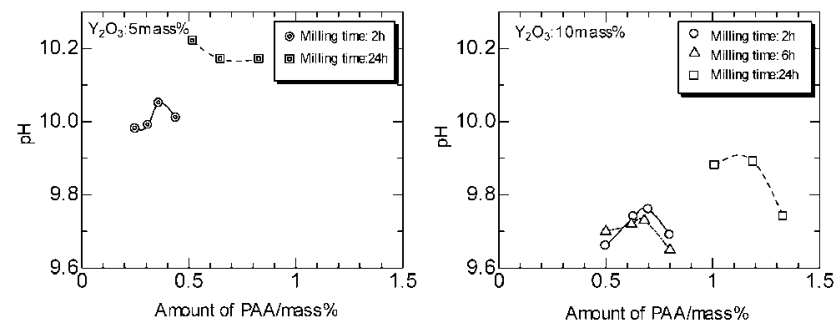

Fig. 2. pH of slurry as a function of PAA amount.
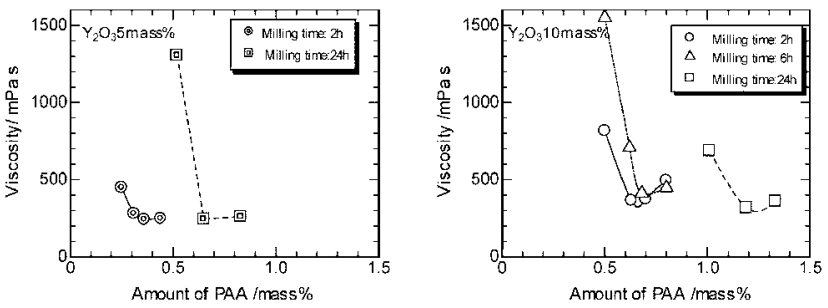

Fig. 3. Apparent viscosity of slurry as a function of PAA amount.
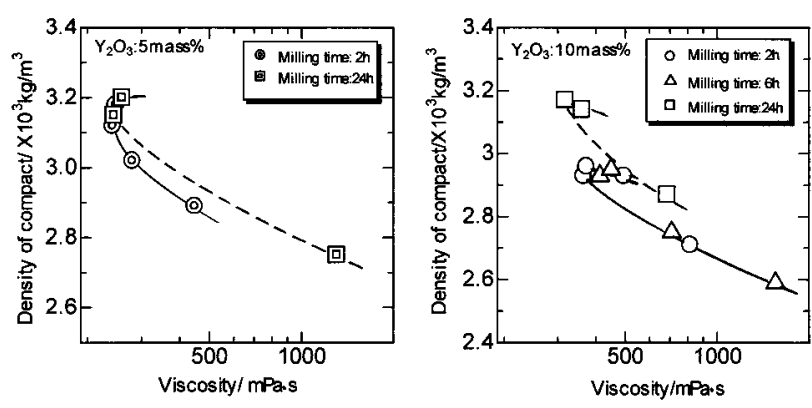

Fig. 4. Relationship between density of compact and apparent viscosity of slurry.

合は, 粘度がほぼ同じであるスラリーにおいても $24 \mathrm{~h}$ 混合の方 が成形体密度は高くなり, 長時間混合することで密度の大きな 成形体となった。

図 5 にイットリアを10 mass\%添加した場合の PAA 添加量と 成形体の比表面積の関係を示す.いずれの混合時間においても PAA 添加量が増加するほど成形体の比表面積も増加した.こ れは成形体中の比表面積に固化したPAA も含まれるためと思 


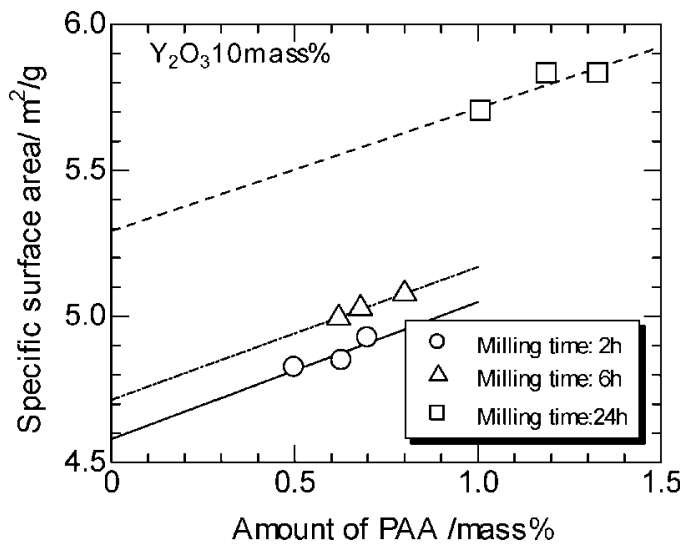

Fig. 5. Specific surface area of compact with 10 mass $\% \mathrm{Y}_{2} \mathrm{O}_{3}$ as a function of PAA amount.
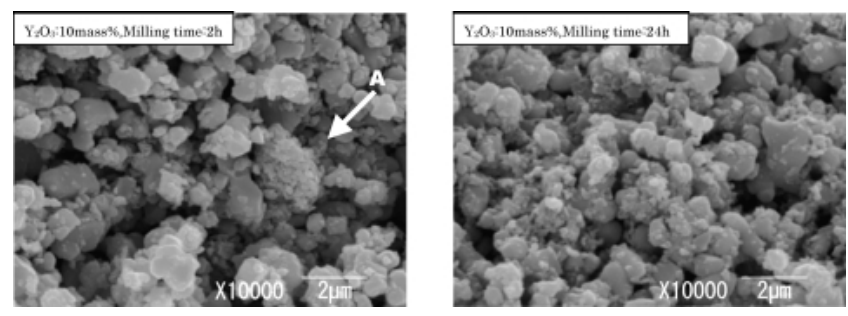

Fig. 6. SEM photograph of compact with 10 mass $\% \mathrm{Y}_{2} \mathrm{O}_{3}$.

われる.そこで混合時間ごとにPAA 添加量に対する 1 次の直 線に近似し，その切片を粉体のみの比表面積と考えた．その結 果を用いると, 混合時間が長くなるほど粉体の比表面積は増加 することが示された. 原料粉体の比表面積から求めたイットリ ア 10 mass\%を含む比表面積は $4.5 \mathrm{~m}^{2} / \mathrm{g}$ であり，どの混合時間 の比表面積もそれより大きな值を示した．特に，24h 混合では $2 \mathrm{~h}$ 混合よりおよそ1.2倍比表面積が大きくなった.

図 6 にイットリア 10 mass\%添加した成形体の破面のSEM 観 察像を示す。 $24 \mathrm{~h}$ 混合の成形体では窒化チタン粒子に付着する ように微細なイットリア粒子が存在しているのに対し， $2 \mathrm{~h}$ 混 合ではそうしたイットリア粒子は少ない。また，2 h 混合では 図中の A に示すような数 $\mu \mathrm{m}$ のイットリア粒子の凝集体が存在 した．このことから，短時間混合では微細なイットリア粒子は 窒化チタンと良好に液中混合できず，一部がイットリアのみの 凝集体の状態で成形体に残存することが分かった。

\section{4 焼結体特性}

図 7 に鋳込成形体の密度と焼結体密度の関係を示す。イット リア添加量が 5 mass\%の場合，いずれの混合時間でも密度が大 きな成形体から密度の高い焼結体が得られ, 焼結体に成形体密 度依存性が認められた。一方，イットリア添加量が 10 mass \% の場合, 混合時間が $2 \mathrm{~h}$ と $6 \mathrm{~h}$ では焼結体に成形体密度依存性 が認められたが， $24 \mathrm{~h}$ 混合では成形体の密度にかかわらず，焼 結体は同程度の高い密度となった．また，どちらのイットリア 添加量でも混合時間が長くなるほど焼結体密度は増加した。 イットリアを添加しない場合の雲囲気焼成による焼結体密度は

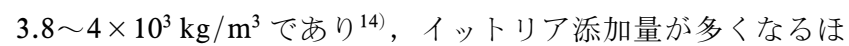
ぞ焼結体密度が高くなり緻密化が進行したことが示された。 た，ホットプレス焼結されたイットリア添加窒化チタンの密度 は 5 mass\%で約 $4.7 \times 10^{3} \mathrm{~kg} / \mathrm{m}^{3}, 10$ mass\%では約 $5.2 \times 10^{3} \mathrm{~kg} /$
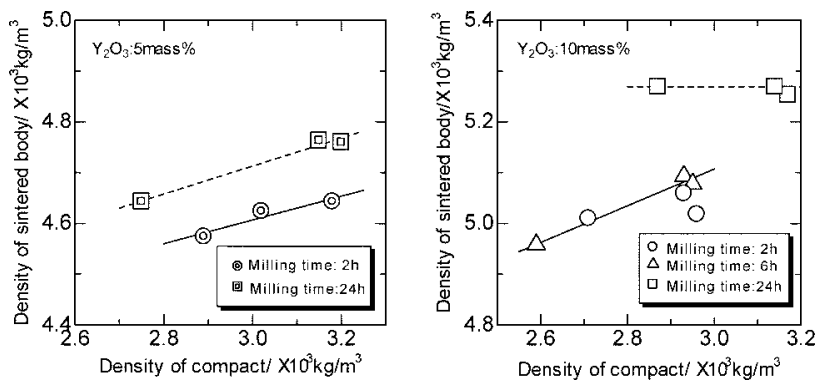

Fig. 7. Relationship between density of sintered body and density of compact.

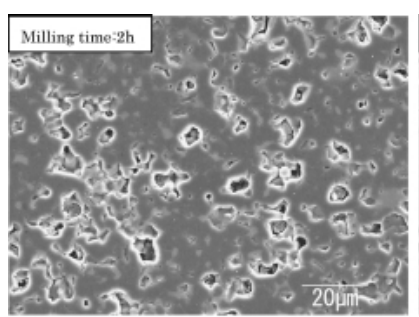

Secondary electron image

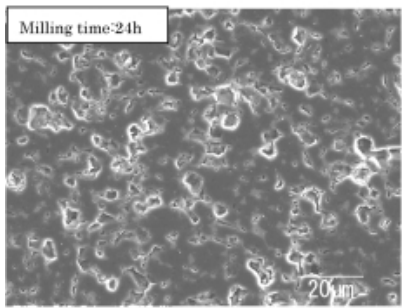

Secondary electron image

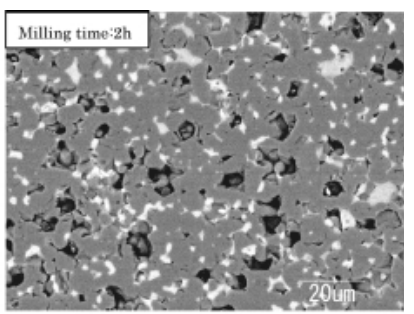

Composition image

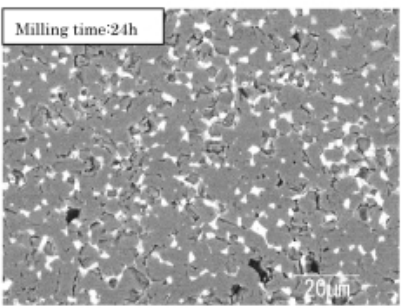

Composition image
Fig. 8. SEM photograph of sintered body with 10 mass $\% \mathrm{Y}_{2} \mathrm{O}_{3}$.

$\mathrm{m}^{3}$ である ${ }^{13)}$. 今回，イットリア添加 10 mass\%で $24 \mathrm{~h}$ 混合した スラリーを水系鋳込成形及び雾囲気焼成することにより，ホッ トプレス焼結と同程度に緻密化させることができた．更に，焼 結体の色は黄金色を有していることから, 装飾用焼結体等への 応用が可能であると思われる.

図 8 にイットリア 10 mass\%添加した焼結体の研削面のSEM 観察像を示す. 図の反射電子像に抢いて白く観察される部分は イットリウムを含む相であり, $\mathrm{X}$ 線回折の結果から $\mathrm{Y}_{2} \mathrm{O}_{3}$ と $\mathrm{Y}_{2} \mathrm{TiO}_{5}$ の結晶が同定された. $2 \mathrm{~h}$ 混合の場合, 2 次電子像から 多くの気孔が観察される. また, 反射電子像では白い相の一部 に大きな塊の存在が確認できる。一方, $24 \mathrm{~h}$ 混合の場合は気孔 が少なく緻密な組織となった。 また, 反射電子像に打ける白い 相により, 窒化チタンの粒界にイットリアが微細に分布してい ることが観察された.

\section{4. 考 察}

\section{1 スラリー及び成形体特性に及ばすイットリア混合条件 の影響}

今回，窒化チタンスラリーにイットリアを添加し混合する と, 混合時間が長くなるほど低粘度のスラリ一調製に必要な分 散剂が増加した. 図 3 より, イットリア添加量を 2 倍に増やし た場合, 最小の見掛け粘度を得るためのスラリーに必要な分散 剤添加量も約 2 倍に増加していることから，イットリア粉体の 
添加が必要とする分散剤の増加に大きく影響しているものと考 えられる. 更に, 図 5 よりスラリーの混合時間が長くなるほど 成形体中の粉体の比表面積も増加することが考察されている. 長時間混合によるこのような比表面積の増加は, PAA 添加量 が増加した一因であると考えられる. 水系混合により比表面積 が増大した原因をより詳細に解明するためには，イットリア粉 体の表面状態分析などの解析が必要であり, 今後さらに検討を 行う予定である.

次に，スラリー中のイットリア粒子の分散性が成形体特性に 及ぼす影響について検討する，図 4 より，いずれの混合時間で も粘度が低いスラリーから大きな密度の成形体が得られた.こ のことは既に報告した ${ }^{14)}$ 結果とほぼ同様の傾向である. 一方, イットリア 10 mass\%添加した場合，ほぼ同じスラリー粘度で あるにもかかわらずスラリーを長時間混合することにより密度 の高い成形体が得られた。この原因を考察するために, 図 6 の 成形体内部の SEM 観察結果を見ると, 短時間混合ではイット リアの一部が凝集体として残存しているものも, 長時間混合で はイットリアは成形体中で窒化チタン粉体に付着するように存 在していた。このことにより，スラリーの見掛け粘度が同じで も, イットリアの液中分散状態の違いにより, 成形体密度に大 きな差が現れたものと考察される.

\section{2 焼結特性に及ぼすイットリア混合条件の影響}

今回, 図 7 に示すように高密度の成形体から高密度の焼結体 が得られるとともに, 長時間混合するほど焼結体密度は向上し た. また, 図 8 のSEM 像に打いて, 短時間混合の焼結体は気 孔が多くかつ大きなイットリア相の存在が観察されるのに対 し, 長時間混合の焼結体はイットリア相が焼結体全体に微細に 分布している.このことから, 長時間混合を行うことによっ て, イットリア粒子がスラリー中に均一に分散し，その結果成 形体及び焼結体密度が向上したと考える.このことは図 2 に示 すスラリー pH が, 図 1 にみられるようにイットリアには正の 窒化チタンには負のゼータ電位を示す領域であるため, 窒化チ タン基礎スラリーにイットリアを添加した際にへテロ凝集状態 になり, 短時間混合ではその凝集構造が破壊されにくいことも 関係しているものと思われる. また, 長時間ボールミル混合に よって比表面積が増大していることからも窒化チタンの粉砕 . 分散が焼結体密度の向上に影響している可能性がある.イット リア 5 mass \%の焼結体は 3〜 5\%の吸水率が認められ，完全な 緻密化に至っていない．これはイットリア添加量が不足してい るためであり，その結果混合時間にかかわらず暁結体に成形体 密度依存性が認められたものと思われる. 一方, イットリア添 加量が 10 mass \%の場合, 短時間混合では焼結体に成形体密度 依存性が認められるが, 長時間混合では成形体密度が変化して もほぼ一定の高い密度となった．窒化ケイ素の鋳込成形におい ても $1 \mathrm{~h}$ 混合スラリーからの焼結体では成形体密度依存性があ $\eta^{20)}, 16 \mathrm{~h}$ 混合スラリーからの焼結体では, 成形体密度依存性 は認められていない15) 17)。このことから, 図8 にみられるよ うに, 長時間混合したスラリーではイットリア粒子が微細かつ 均一に分散し, 成形体全体に焼結助剂として寄与するため成形 体密度が同じであるにもかかわらず, 長時間混合の方が緻密化 が促進されたと思われる。

\section{5. 結 言}

（1）窒化チタンにイットリアを添加し，水系鋳込成形及び 雾囲気焼成することにより黄金色でホットプレス焼結と同程度 の密度を有する焼結体を作製することができた。
（2）イットリアの窒化チタンへの添加量が高いほど，スラ リー混合時間が長いほど, スラリー粘度を最小とする分散剂添 加量は増加した。

（3）長時間混合スラリーの鋳込成形により，イットリアが 均質に分散した成形体が得られた。 その結果, スラリーの粘度 が同じでも長時間混合の方が成形体密度は高くなった.

（4）上記成形体の焼成により，窒化チタンの粒界にイット リアが微細に分布した緻密構造の焼結体が得られた。

（5）以上の焼結体構造の形成に対して, イットリアと窒化 チタンの混合状態が大きく影響することを実験的に明らかにし た。

\section{References}

1) Chushokigyoujigyoudan Chushoukigyoukenkyusho ed., "Zairyo Riyou Handbook," Nikkan Kogyo Shinbunsha (1988) pp. 245-291 [in Japanese].

2) Ichinose, N. and Kuwahara, H., "NITRIDE CERAMICS," Nikkan Kogyo Shinbunsha (1998) pp. 119-126 [in Japanese].

3) Yasutomi, Y., Nakamura, K., Sobue, M. and Kubo, Y., J. Ceram. Soc. Japan, Vol. 97, pp. 148-154 (1989) [in Japanese].

4) Kuzjukévičs, A., Ishizaki, K., Grabis, J., Millers, T. and Kondo, Y., J. Ceram. Soc. Japan, Vol. 102, pp. 225-230 (1994).

5) Akimune, Y., Munakata, F., Ando, M., Okamoto, Y. and Hirosaki, N., J. Ceram. Soc. Japan, Vol. 105, pp. 122-125 (1997) [in Japanese].

6) Ueno, K., Inoue, T., Sodeoka, S., Suzuki, M., Ishikawa, H., Uchiyama, K. and Inui, T., J. Ceram. Soc. Japan, Vol. 105, pp. 304-307 (1997).

7) Li, J., Gao, L. and Gue, J., J. Eur. Ceram. Soc., Vol. 23, pp. 69-74 (2003).

8) Iwata, Y., Shimada, T. and Kurachi, K., R. Gifu Pref. Ceram. Res. Ins., pp. 1-4 (1995) [in Japanese].

9) Tsuge, A., Inoue, H. and Komeya, K., J. Ceram. Soc. Japan (Yogyo-Kyokai-Shi), Vol. 82, pp. 587-595 (1974).

10) Mitani, H., Nagai, H. and Fukuhara, M., J. Metal. Soc. Japan, Vol. 42, pp. 582-588 (1978) [in Japanese].

11) Yamada, T., Shimada, M. and Koizumi, M., Am. Ceram. Soc. Bull., Vol. 59, pp. 611-616 (1980).

12) Moriyama, M., Kamata, K. and Kobayashi, Y., J. Ceram. Soc. Japan, Vol. 99, pp. 286-291 (1991) [in Japanese].

13) Moriyama, M., Aoki, H., Kobayashi, Y. and Kamata, K., J. Ceram. Soc. Japan, Vol. 101, pp. 279-284 (1993) [in Japanese].

14) Yokoyama, H., Kato, N., Nomura, T., Hotta, T., Nakahira, K., Naito, M., Sakamoto, W. and Hirano, S., J. Ceram. Soc. Japan, Vol. 107, pp. 968-972 (1999) [in Japanese].

15) Oda, K., Mizuta, H., Shibasaki, Y. and Ohshima, K., J. Ceram. Soc. Japan, Vol. 100, pp. 714-719 (1992) [in Japanese].

16) Ohshima, K., Oda, K. and Shibasaki, Y., J. Ceram. Soc. Japan, Vol. 100, pp. 1032-1037 (1992) [in Japanese].

17) Ohshima, K., Oda, K., Sano, S. and Shibasaki, Y., J. Ceram. Soc. Japan, Vol. 101, pp. 416-421 (1993) [in Japanese].

18) Naito, M., Fukuda, Y., Yoshikawa, N., Kamiya, H. and Tsubaki, J., J. Eur. Ceram. Soc., Vol. 17, pp. 251-257 (1997).

19) Kamiya, H., Naito, M., Hotta, T., Isomura, K., Tsubaki, J. and Uematsu, K., Am. Ceram. Soc. Bull., Vol. 76, pp. 79-82 (1997).

20) Albano, P. M. and Garrido, B. L., J. Am. Ceram. Soc., Vol. 81, pp. 837-844 (1998).

21) Seaverson, L. M., Luo, S. Q., Chien, P. L. and Mcclelland, J. F., J. Am. Ceram. Soc., Vol. 69, pp. 423-429 (1986).

22) Yaserbe, M., Moroz, M. Z., Kemp, W. and Sturgis, D. H., J. Am. Ceram. Soc., Vol. 79, pp. 1223-1227 (1996).

23) Uchikoshi, T., Hisashige, T. and Sakka, Y., J. Ceram. Soc. Japan, Vol. 110, pp. 840-843 (2002) [in Japanese]. 